\title{
Troponin-T Levels Can Predict Left Ventricle Remodeling in Chronic Hemodialysis Patients
}

\author{
Troponin-T Düzeyleri Kronik Hemodiyaliz Hastalarında \\ Sol Ventrikül Remodelingini Öngörebilir
}

\section{Özgün Araştrrma} Research Article
Alındığı tarih: 23.11 .2019

Kabul tarihi: 26.12 .2019 Online Yayın tarihi: 28.03.2020

Cenk Ekmekci Health Sciences University, Tepecik Traning and Education Hospital, Department of Cardiology Izmir, Turkey cenkekmekci@yahoo.com ORCiD: 0000-0001-7130-4819

H. Colak 0000-0003-2867-6937 Health Sciences University, Tepecik Traning and Education Hospital, Department of Nephrology, Izmir, Turkey

O. Bayturan 0000-0003-2500-9629 U.K. Tezcan 0000-0002-2445-8089

A.R. Bilge 0000-0002-3644-205X Department of Cardiology, Celal Bayar University, Faculty of Medicine, Manisa, Turkey

S. Kursat 0000-0001-9437-8474 Department of Nephrology, Celal Bayar University, Faculty of Medicine, Manisa, Turkey

Cite as: Ekmekci C, Çolak H, Bayturan O, Kursat S, Tezcan UK, Bilge AR. Troponin-T levels can predict left ventricle remodeling in chronic hemodialysis patients. Tepecik Eğit. ve Araş. Hast. Dergisi. 2020;30(1):12-8.

\author{
Cenk Ekmekci $\odot$, Hulya Colak $\odot$, Ozgur Bayturan $\odot$, Seyhun Kursat $\odot$, Ugur Kemal Tezcan $\odot$, \\ Ali Riza Bilge $\odot$
}

\begin{abstract}
Objective: Cardiac troponin $T(\mathrm{CTnT})$ is an important marker in patients with chronic renal failure (CRF) in the prediction of cardiovascular outcomes. We aimed to evaluate whether CTnT levels will provide further information about left ventricular geometric pattern in CRF as the result of patient's volume status and efficacy of hemodialysis. Method: Sixty-one patients who underwent hemodialysis three times a week for more than 3 months (mean 19 months) were included the study. One day before the mid-dialysis session, blood samples were taken from the patients in the hemodialysis program and cTnT was studied. All patients underwent echocardiographic examination one day before the second hemodialysis session of the week by the same cardiologist.

Results: When the groups were compared in terms of echocardiographic volume parameters; left atrium diameter, left ventricle (LV) mass, LV mass index were found to be higher in the cTnT positive group. The eccentric LV hypertrophy pattern was significantly more frequent in the cTnT-positive group (p:0.04).

Conclusion: $c T n T$ levels increase in hemodialysis patients with eccentric LV hypertrophy as the result of hypervolemia. In conclusion, CTnT could be used as a marker of LV geometric pattern and as a method for planning the treatment modalities in hemodialysis patients.
\end{abstract}

Keywords: cTnT, hemodialysis, echocardiographic volume parameters, left ventricular eccentric hypertrophy

öz

Amaç: Kronik böbrek yetmezliği (KBY) olan hastalarda kardiyak troponin T (cTnT), kardiyovasküler sonuçları öngörmede önemli bir belirteçtir. cTnT düzeylerinin, hemodiyalizin etkinliği ve hastanın volüm durumunun bir sonucu olarak; $K B Y^{\prime}$ deki sol ventrikül geometrik paterni hakkında daha fazla bilgi sağlayıp sağlamadığını değerlendirmeyi amaçladık.

Yöntem: Çalışmaya 3 aydan fazla (haftada 19 ay), haftada üç kez hemodiyaliz yapılan, altmış bir hasta dahil edildi. Hemodiyaliz programındaki hastalardan orta diyaliz seansından bir gün önce kan örnekleri alındı ve cTnT çalışıldı. Tüm hastalara aynı kardiyolog tarafından haftanın ikinci hemodiyaliz seansından bir gün önce ekokardiyografik inceleme yapıldı.

Bulgular: Gruplar ekokardiyografik volüm parametreleri açısından karşılaştırıldığında; cTnT pozitif grupta sol atriyum çapı, sol ventrikül (SV) kitlesi, SV kitle indeksi daha yüksek bulundu. Egzantrik SV hipertrofi paterni, cTnT-pozitif grupta anlamlı olarak daha sıktı (p:0,04).

Sonuç: Hipervolemiye sekonder gelişen egzantrik sol ventrikül hipertrofisi olan hemodiyaliz hastalarında cTnT artmaktadır. Sonuç olarak, cTnT hemodiyaliz hastalarında LV geometrik paterninin bir yol göstericisi ve tedavi yöntemlerinin planlanması için bir yöntem olarak kullanılabilir.

Anahtar kelimeler: $\mathrm{CTnT}$, hemodiyaliz, ekokardiyografik volüm parametreleri, egzantrik sol ventrikül hipertrofisi

(c) Telif hakkı T.C. Sağlık Bakanlığı izmir Tepecik Eğit. ve Araşt. Hastanesi. Logos Tıp Yayıncılık tarafindan yayınlanmaktadır. Bu dergide yayınlanan bütün makaleler Creative Commons Attf-GayriTicari 4.0 Uluslararası Lisansı ile lisanslanmıştır.

(c) Copyright Association of Publication of the T.C. Ministry of Health izmir Tepecik Education and Research Hospital. This journal published by Logos Medical Publishing.

Licenced by Creative Commons Attribution-NonCommercial 4.0 International (CC BY-NC 4.0) 


\section{INTRODUCTION}

Cardiac troponin $\mathrm{T}$ (cTnT) is an important parameter to predict outcomes of myocardial diseases ${ }^{(1)}$. The use of troponins in patients with chronic renal failure (CRF) is steadily increasing and it is thought to be a powerful guide in terms of predicting cardiovascular outcomes in this population (2). Echocardiography together with measurement of cTnT in dialysis patients increases the importance of these markers. Left ventricular (LV) hypertrophy is considered an important predictor of cardiovascular outcome, independent of patient's characteristics and risk factors ${ }^{(3)}$. All hemodialysis patients were divided into four groups according to left ventricular mass (LVM) patterns. Increased LVM is subdivided into concentric left ventricular hypertrophy (cLVH) and eccentric left ventricular hypertrophy (eLVH). In contrast to eLVH, relative wall thickness (RWT) is increased in comparison with dimensions of left ventricular cavity in cLVH. Both eLVH and cLVH are associated with a 2-to 3-fold increased CVD risk, if compared to hemodialysis patients without LVH. From the pathophysiologic view, an increase in afterload like increased arterial stiffness could induce cLVH, whereas volume overload (anemia and hypervolemic states) leads to eLVH (4). In hemodialysis patients the simultaneous coexistence of different risk factors like hypertension, hypervolemia, and anemia may alter LV geometry. The risk of sudden death in hemodialysis patients is 5 -fold greater in patients with eLVH than with cLVH. Early recognition of an unfavorable LV type and timely intervention may have a beneficial effect on clinical outcomes in these patients with risk of sudden death. In this study, the relationships among cTnT levels, clinical, laboratory findings, and echocardiographic volume parameters in chronic hemodialysis (HD) patients without acute coronary syndrome were evaluated. We investigated whether cTnT levels will provide further information about LV remodeling in hemodialysis patients dependent on patient's volume status and efficacy of hemodialysis.

\section{MATERIAL and METHODS}

Sixty-one hemodialysis patients who were admitted to our Internal Medicine Department Division of Nephrology for follow-up and treatment were enrolled in the study. All patients included in the study attended hemodialysis sessions three times a week for at least 3 months (median 19 months). Patients who had been treated with hemodialysis for less than 3 months, those with acute coronary syndrome (ACS), cardiomyopathy (CMP), chronic liver disease, and marked history of heart valve disease were excluded from the study. Acute coronary syndrome was defined as anginal chest pain accompanied by ischemic findings on electrocardiography and wall motion abnormalities in echocardiography. Blood samples were taken 1 day before the mid-dialysis session in a week from patients in the hemodialysis program, and levels of hemoglobin ( $\mathrm{Hgb})$, hematocrit (Htc), creatinine, LDL-cholesterol (LDL-C), HDL-cholesterol (HDL-C), total cholesterol (TC), triglyceride (TG) and cTnT were measured. cTnT was studied with electrochemiluminescence method using Roche cTnT stat kit (Roche Diagnostics GmbH Mannheim, Germany) in Roche Elecsys 1010.device. The measurement range of the device was $0.01-25 \mu \mathrm{g} / \mathrm{L}$ or $\mathrm{ng} / \mathrm{ml}$ with analytical sensitivity of $0,01 \mu \mathrm{g} / \mathrm{L}$ or $\mathrm{ng} / \mathrm{ml}$, and CV $10 \%$ of $0.01 \mu \mathrm{g} / \mathrm{L}$ or $\mathrm{ng} / \mathrm{ml}$. Patients were divided into cTnT-positive ( $\geq 0.1 \mu \mathrm{g} / \mathrm{L}$ ) and cTnT-negative $(<0.1 \mu \mathrm{g} / \mathrm{L})$ groups. Following these evaluations, all patients underwent echocardiographic evaluation by the same person using the same device one day before the $2^{\text {nd }} \mathrm{HD}$ session of the week according to the recommendations of the American Society of Echocardiography ${ }^{(5)}$. Echocardiography was performed with Vivid-3 Image Point echocardiography device using $1.7 \mathrm{MHz}$ cardiac probe. Left ventricular end-systolic diameter (LVESD), left ventricular enddiastolic diameter (LVEDD), left atrial diameter (LAD), and thickness of interventricular septum (IVS) and left ventricular posterior wall (LVPW) were measured using two-dimensional echocardiography ${ }^{(6)}$. Left ventricular ejection fraction (LVEF) was calculated 
from the apical four cavity using the Simpson method ${ }^{(7)}$. LVM was calculated using the thick-wall prolate-ellipsoidal model ${ }^{(8)}$. LVM was normalized by calculating the LVM index (LVMI). LVMI was calculated by dividing LVM with body surface area (BSA) according to the following formula:

LVMI $\left(\mathrm{g} / \mathrm{m}^{2}\right)=(\mathrm{BSA}) /\left(\mathrm{BSA}=0.007184 \mathrm{x}[\text { weight }(\mathrm{kg})]^{0.425} \mathrm{x}\right.$ [height $(\mathrm{cm})\}^{0.725}$

${ }^{(9,10)}$. Upper limits of LVMI were accepted as $131 \mathrm{~g} / \mathrm{m}^{2}$ in men and $100 \mathrm{~g} / \mathrm{m}^{2}$ in women ${ }^{(11)}$. The Relative Wall Thickness (RWT) of the left ventricle was calculated using the [RWT = $2 \times$ (LVPWT / LVEDD]) formula and the upper limit of RWT was calculated as 0.44 . The geometric pattern of the left ventricle was estimated according to the method of Ghanau et al. ${ }^{(12)}$ normal geometry (NG): was divided into groups as follows: normal LVMI, normal RWT, concentric remodeling (CR): normal LVMI; increased RWT, CLVH: increased LWMI, increased RWT and eLVH: increased LVMI, and normal RWT. Diameter of vena cava Inferior $(\mathrm{VCl})$ was measured with the patient lying in the supine position for 10 minutes after resting, and one day after the mid-week HD session. All vasoactive drugs were discontinued within 24 hours before the initiation of the study.

During the measurements, the $\mathrm{VCl}$ diameter was measured during maximal inspiration and expiration by taking into account of the patient's avoidance of the Valsalva maneuver ${ }^{(13)}$. Collapsibility index of $\mathrm{VCI}$ was calculated as follows: (maximum diameter of $\mathrm{VCl}$ on expiration-minimal diameter of $\mathrm{VCl}$ in deep inspiration/maximum diameter of $\mathrm{VCl}$ on expiration) The left atrial diameter was measured in the parasternal long axis at the end of the systole in the expirium with the line $M$ perpendicular to the aortic root. The data were analyzed using SPSS 11.0 computer statistics package program. Descriptive statistics, Mann-Whitney $U$ test, Spearman correlation test, Kruskal-Wallis test and chi-square $t$ test were used in all statistical analyzes. The $p$ value $<0.05$ was considered as statistically significant.

\section{RESULTS}

The mean ages of the cTnT-positive, and negative groups were $58.4 \pm 13.8$ and $56.2 \pm 15.9$ years, respectively. There was no significant difference between the two groups in terms of demographic and clinical data except for DM (diabetes mellitus) and cardiothoracic index (Table 1). When the groups were compared in terms of echocardiographic volume parameters, LV end-diastolic diameter, LA diameter, LVM, LVMI and VCl diameters on inspiration were higher

Table 1. Demographic and laboratory features.

\begin{tabular}{lccc}
\hline & $\begin{array}{c}\text { cTnT positive } \\
\text { (n:22) }\end{array}$ & $\begin{array}{c}\text { cTnT negative } \\
\text { (n:39) }\end{array}$ & $\begin{array}{c}\text { p } \\
\text { value }\end{array}$ \\
\hline Age (year) & $58.4 \pm 13.8$ & $56.2 \pm 15.9$ & 0.60 \\
Male & 11 & 17 & 0.62 \\
Hypertension & $16(72.7 \%)$ & $22(56.4 \%)$ & 0.20 \\
Diabetes mellitus & $11(50.0 \%)$ & $8(20.5 \%)$ & 0.01 \\
BMl (kg/m $\left.{ }^{2}\right)$ & $23.3 \pm 4.8$ & $22.7 \pm 4.7$ & 0.64 \\
Creatinine (mg/dl) & $6.6 \pm 2.3$ & $6.6 \pm 2.4$ & 0.99 \\
LDL-C (mg/dl) & $99.7 \pm 35.8$ & $104.7 \pm 42.7$ & 0.64 \\
HDL-C (mg/dl) & $36.1 \pm 11.1$ & $41.1 \pm 12.1$ & 0.11 \\
TG (mg/dl) & $161.8 \pm 77.4$ & $180.2 \pm 96.3$ & 0.44 \\
TC (mg/dl) & $161.5 \pm 53.6$ & $177.7 \pm 49.6$ & 0.23 \\
Hb (gr/dl) & $10.072 \pm 1.053$ & $10.1 \pm 1.7$ & 0.91 \\
Htc (\%) & $30.045 \pm 3.499$ & $30.4 \pm 5.6$ & 0.76 \\
CTI & $0.562 \pm 346$ & $0.509 \pm 313$ & $\mathbf{0 . 0 2}$ \\
\hline
\end{tabular}

cTnT: Cardiac Troponin T, BMI: Body Mass Index, LDL-C: Low-Density Lipoprotein-Cholesterol, HDL-C: High-Density Lipoprotein-Cholesterol, TG: Triglyceride, TC: Total Cholesterol, Hb: Hemoglobin, Htc: Hematocrit, CTI: Cardiothoracic Index.

Table 2. Echocardiographic volume parameters.

\begin{tabular}{lccc}
\hline & $\begin{array}{c}\text { cTnT positive } \\
\text { (n:22) }\end{array}$ & $\begin{array}{c}\text { cTnT negative } \\
\text { (n:39) }\end{array}$ & $\begin{array}{c}\text { p } \\
\text { value }\end{array}$ \\
\hline LA (cm) & $3.8 \pm 0.8$ & $3.4 \pm 0.6$ & $\mathbf{0 . 0 2}$ \\
IVS (cm) & $1.2 \pm 0.2$ & $1.1 \pm 0.2$ & 0.10 \\
LVPW (cm) & $1.2 \pm 0.2$ & $1.1 \pm 0.1$ & 0.06 \\
IVS/LVPW & $1.0 \pm 0.6$ & $1.0 \pm 0.9$ & 0.31 \\
LVEDD (cm) & $4.6 \pm 0.5$ & $4.4 \pm 0.4$ & $\mathbf{0 . 0 4}$ \\
LVESD (cm) & $3.0 \pm 0.6$ & $2.8 \pm 0.5$ & 0.12 \\
LVEF (\%) & $52.8 \pm 8.1$ & $54.4 \pm 7.4$ & 0.44 \\
LVM (gr) & $237.3 \pm 69.0$ & $198.1 \pm 44.6$ & $\mathbf{0 . 0 0 9}$ \\
LVMI (gr/m $\left.{ }^{2}\right)$ & $137.8 \pm 29.8$ & $122.3 \pm 26.4$ & $\mathbf{0 . 0 3}$ \\
VCI expiratory diameter (cm) & $1.8 \pm 0.4$ & $1.7 \pm 0.2$ & 0.13 \\
VCI inspiratory diameter (cm) & $1.1 \pm 0.3$ & $0.93 \pm 0.27$ & $\mathbf{0 . 0 0 6}$ \\
CI (\%) & $0.37 \pm 0.22$ & $0.45 \pm 0.10$ & $\mathbf{0 . 0 0 2}$ \\
VCI INDEX (cm/m ${ }^{2}$ ) & $1.08 \pm 0.24$ & $1.04 \pm 0.17$ & 0.52 \\
LA INDEX (cm $/ \mathrm{m}^{2}$ ) & $2.29 \pm 0.50$ & $2.13 \pm 0.40$ & 0.19 \\
RWT & $0.50 \pm 0.51$ & $0.61 \pm 0.49$ & 0.39 \\
& & &
\end{tabular}

LA: Left Atrium, IVS: Interventricular Septum, LVPW: Left Ventricular Posterior Wall, LVEDD: Left Ventricular End-Diastolic Diameters, LVESD: Left Ventricular End-Systolic Diameters, LVEF: Left Ventricular Ejection Fraction, LVM: Left Ventricul Mass, LVMI: Left Ventricul Mass Index, VCl: Vena Cava Inferior, Cl: Collapsibility Index, RWT: Relative Wall Thickness. 
in the cTnT-positive group, while $\mathrm{VCl}$ collapsibility index was lower. These results were statistically significant (Table 2). HD sessions were maintained for an average of 19 months. Etiologies of primary kidney disease were chronic glomerulonephritis in 7 (11.5\%), hypertensive nephrosclerosis in 11 (18\%), diabetic nephropathy in 19 (31\%) cases, while other causes were detected in 24 (39.3\%) patients.

The frequency of changes in the left ventricular geometric pattern detected by echocardiography in patients enrolled in the study was $53 / 6186 \%$ based on the following formula ( $\mathrm{K}+\mathrm{eLVH}+\mathrm{cLVH} /$ whole patient population), while the frequency of LVH was $43 / 6170 \%$, as estimated according to the following formula (eLVH+cLVH/whole patient population) When the groups were compared in terms of left ventricular geometric patterns, a significant intergroup difference was detected. That is, changes in the left ventricular geometry pattern were observed more frequently in the cTnT- positive group (Table 3 ). Subgroup analysis of the significant difference in left ventricular geometric pattern was performed between the groups. The eccentric left ventricular hypertrophy pattern was significantly more frequent in the cTnT-positive group (Table 4). Another subgroup analysis performed to detect significant differences in the pattern of left ventricular geometry, demons-

Table 3. Left ventricular geometric patterns.

\begin{tabular}{lccc}
\hline Geometric patterns & $\begin{array}{c}\text { cTnT negative } \\
\text { (n:39) }\end{array}$ & $\begin{array}{c}\text { cTnT positive } \\
\text { (n:22) }\end{array}$ & $\begin{array}{c}\text { p } \\
\text { value }\end{array}$ \\
cLVH & $14(35.9 \%)$ & $11(50 \%)$ & \\
eLVH & $8(20.5 \%)$ & $10(45.5 \%)$ & $\mathbf{0 . 0 1 1}$ \\
CR & $10(25.6 \%)$ & & \\
Total & $32 / 39(82 \%)$ & $21 / 22(95.4 \%)$ & \\
& &
\end{tabular}

cLVH: Concentric Left Ventricular Hypertrophy, eLVH: Eccentric Left Ventricular Hypertrophy, CR: Concentric Remodeling.

Table 4. Subgroup analysis of change in left ventricular geometric patterns.

\begin{tabular}{lccc}
\hline Geometric patterns & $\begin{array}{c}\text { cTnT negative } \\
\text { (n:39) }\end{array}$ & $\begin{array}{c}\text { cTnT positive } \\
\text { (n:22) }\end{array}$ & $\begin{array}{c}\mathbf{p} \\
\text { value }\end{array}$ \\
\hline CLVH & $14(35.8 \%)$ & $11(50.0 \%)$ & 0.10 \\
eLVH & $8(20.5 \%)$ & $10(45.4 \%)$ & $\mathbf{0 . 0 4}$ \\
\hline
\end{tabular}

trated statistically insignificant differences between cTnT-negative, and cTnT-positive groups in terms of left ventricular concentric pattern (Table 4) (Figure 1).

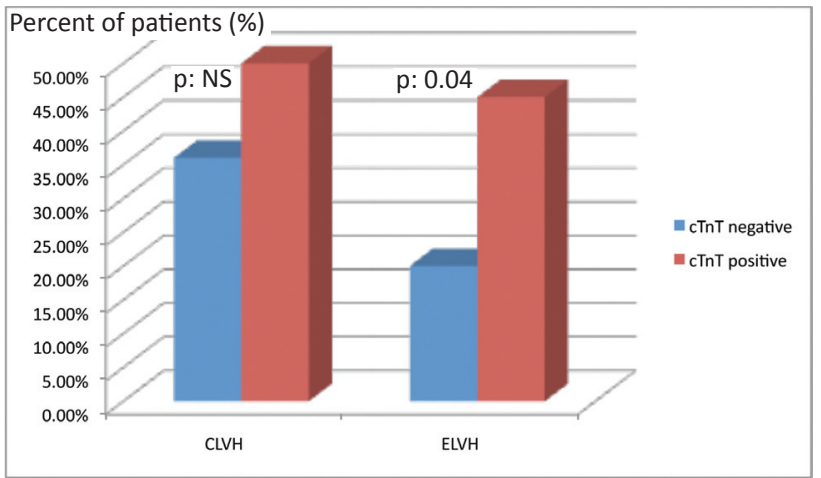

CLVH: Concentric left ventricle hypertrophy

ELVH: Eccentric left ventricle hypertrophy

Figure 1. Subgroup analysis of change in left ventricular geometry pattern.

\section{DISCUSSION}

We have reported that elevated cTnT levels could predict eLVH in hemodialysis patients as a result of hypervolemia. In a recent study, Myhre et al. ${ }^{(14)}$ reported the relationship of cTnT concentrations with both LV mass and reversible myocardial ischemia in patients with suspected stable CAD. However, this is the first study that indicates the relationship of cTnT levels and LV geometric patterns in hemodialysis patients. Hypertension and atherosclerosis could cause an increase in left ventricular systolic pressure and consequently CLVH in these patients. On the other hand, eccentric hypertrophy, which is defined by the increase in the length of myocardial fibers and left ventricular volume, develops secondary to hypervolemia and anemia resulting from accumulation of water and salt in CRF. While the pressure load in dialysis patients primarily causes an increase in LV Mass, LV dilatation is frequently observed in the case of chronic volume burden ${ }^{(15)}$. According to Laplace's law; wall stress is directly proportional to internal diameter of LV and pressure, and inversely proportional to LV wall thickness. Volumetric load increases the wall thickness in equal proportion with increasing diameter, and expanding ventricular cavities, so the ratio between the 
diameter and the wall thickness remains within normal limits. In case of the pressure load, increase in wall tension is manifested by a disproportionate increase in the LV wall thickness of the normal diameter of the ventricular cavity. This condition is reflected as cLVH on echocardiograms. Accurate volumetric evaluation of fluid status in dialysis patients can be demonstrated by measurement of the diameter of $\mathrm{VCl}$ by echocardiography and reduction of its diameter in deep inspiration ${ }^{(16)}$. Echocardiographic measurement of $\mathrm{VCl}$ is a simple, rapid and noninvasive method for evaluating the intravascular volume status. In accordance with these reports our study has shown that the fluid load in dialysis patients resulted in inadequate volume and blood pressure control ensuing in eccentric and concentric ventricular hypertrophy. Hypervolemia is an important, and frequently encountered problem in hemodialysis patients because of non-compliance with dietary recommendations and inaccurate calculation of dry weight. For the determination of this clinical entity; it has been reported that the increase in diameters of $\mathrm{VCl}$ and $\mathrm{LA}$ in echocardiography can be used to evaluate the volume status in dialysis patients ${ }^{(17)}$. Similarly, it was stated that hypervolemia contributes to increase in left ventricular mass index in uncontrolled hypertensive patients ${ }^{(18)}$. In the light of these literature, and based on the results of our study, it can be easily said that hypervolemia is a factor that induces dilatation of the left atrium, decrease in collapsibility index and increase in the left ventricular mass. Detection of deterioration in these parameters in the cTnT-positive group, is possibly associated with poor volume control and hypervolemia. As is known, gradually increasing derangement of volume balance leads to cTnT elevation. CTI was significantly higher in the cTnT-positive group. LVH, LV dilatation and pericardial effusion, which was shown to be associated with CTI is also thought to be correlated with hypervolemia. Increased volume burden in chronic HD patients was significantly associated with cTnT positivity. Increased levels of cTnT, which are known to be associated with poor prognosis in end-stage renal disease, are found to be higher in patients with high volume burden, suggesting that tight volume control in this group of patients may decrease cardiac mortality. cTnT can be used as a marker for the evaluation of hypervolemia in hemodialysis patients and as a method for modifying treatment modalities. In the study of Foley et al. ${ }^{(19)}$, increased cavity volume $\left(120 \mathrm{ml} / \mathrm{m}^{2}\right)$ was found to be independently related to long-term mortality in dialysis patients with normal systolic function and LV dilatation according to the echocardiographic classification system of prognosis. Cheriex et al. ${ }^{(15)}$ found a significant correlation between central venous pressure and both $\mathrm{VCl}$ and $\mathrm{Cl}$, and also between total blood volume and $\mathrm{VCl}$ index. In many studies hypervolemia was evaluated based on the measurements of the left ventricular end-systolic, end-diastolic, and atrial diameters, left atrial volume index, $\mathrm{Cl}, \mathrm{VCl}$, and its decrease in deep inspiration ${ }^{200}$. Insulin resistance in DM induces macrovascular disease due to hypertension, and hyperinsulinemia caused by microvascular sclerosis (21). Hyperinsulinemia induces water and salt retention, leading to greater volume load in ESRD patients with diabetic nephropathy. As hypervolemia may be associated with troponin positivity, it is concluded that decreased coronary collateral vessel opening capacity and frequency of silent coronary artery disease may lead to elevation of $\mathrm{CTnT}^{(18)}$. Consistent with the aforementioned literature, in our study the significantly greater number of DM patients were detected in the cTnT-positive group.

In our study, although lower hemoglobin values were detected in CTnT-positive patients, any statistically significant intergroup difference was not found. This finding supported that cTnT positivity in patients with chronic HD rather than anemia was the primary problem with volume overload causing eLVH. In addition, lack of any statistically significant difference between cTnT-positive and negative groups in the subgroup analyses related to left ventricular geometry as for cLVH have demonstrated the presence of volume load rather than pressure load in chronic HD. In our study, although high cTnT levels 
were associated with poor cardiovascular outcomes, inability both to monitor patients for longer periods, and to gather adequate information about patients' prognosis due to cross-sectional design of the study was seen as a deficiency of the study. On the other hand, limited number of patients may also lead to questioning the power of statistics used in the study.

There are few studies on the prognostic power of echocardiographic abnormalities in ESRD patients. In a landmark observation of Foley and Parfrey, it has been shown that LVM and LV systolic functions are frequently impaired in ESRD patients ${ }^{(18)}$. Nowadays, it is firmly established that in the dialysis population LVH is a valuable prognostic factor. Especially in the presence of impaired LV systolic function and increased LVMI, maximum increase in cardiovascular risks is observed. As a result, hypervolemia may be a mechanism to explain the relationship between cTnT positivity and increased cardiovascular morbidity, and mortality in chronic hemodialysis patients. As is known in patients with high levels of cTnT, poor cardiovascular outcomes can be attributed to these patients. Therefore, cTnT may be a practical marker in terms of demonstrating cardiovascular adverse outcomes due to volume burden.

In conclusion, we think that increased volume burden in chronic HD patients may be closely related to cTnT-positivity. Higher levels of cTnT, known to be associated with poor prognosis, and detected in patients with cardiovascular diseases, suggest that strict volume control may decrease cardiac mortality and improve prognosis in this group of patients.

Ethics Committee Approval: Celal Bayar University Faculty of Medicine Scientific Ethics Committee approval was obtained (2004-117).

Conflict of Interest: There is no conflict of interest between the authors participating in the study.

Funding: No financial support was received for the study.

Informed Consent: Informed Consent was obtained from all volunteers included in the study.

\section{REFERENCES}

1. Mallamaci F, Zoccali C, Parlongo S, et al. Troponin is related to left ventricular mass and predicts all-cause and cardiovascular mortality in hemodialysis patients. Am J Kidney Dis. 2002;40:68-75. [CrossRef]

2. Dierkes J, Domrose U, Westphal S, et al. Cardiac troponin T predicts mortality in patients with end-stage renal disease. Circulation. 2000;102:1964-9. [CrossRef]

3. Parfrey PS, Foley RN, Harnett JD, Kent GM, Murray DC, Barre $P E$. Outcome and risk factors for left ventricular disorders in chronic uraemia. Nephrol Dial Transplant. 1996; 11:1277-85. [CrossRef]

4. Park M, Hsu CY, Li Y, et al. Associations between kidney function and subclinical cardiac abnormalities in CKD. J Am Soc Nephrol. 2012; 23:1725-34. [CrossRef]

5. American Society of Echocardiography Recommendations for Use of Echocardiography in Clinical Trials J Am Soc Echocardiogr. 2004;17:1086-1119. [CrossRef]

6. Sahn DJ, DeMaria A, Kisslo J, Weyman A. Recommendations regarding quantitation in $\mathrm{M}$-mode echocardiography: results of a survey of echocardiographic measurements. Circulation. 1978; 58: 1072-83. [CrossRef]

7. Importance of imaging method over imaging modality in noninvasive determination of left ventricular volumes and ejection fraction: assessment by two- and three-dimensional echocardiography and magnetic resonance imaging. J Am Coll Cardiol. 2000 Feb;35(2):477-84. [CrossRef]

8. Devereux RB, Alonso DR, Lutas EM, et al. Echocardiographic assessment of left ventricular hypertrophy: comparison to necropsy findings. Am J Cardiol. 1986;57:450-8. [CrossRef]

9. Casale PN, Devereux RB, Milner M, et al. Value of echocardiographic measurement of left ventricular mass in predicting cardiovascular morbid events in hypertensive men. Ann Intern Med. 1986;105:173-8. [CrossRef]

10. Devereux RB, de Simone G, Koren MJ, Roman MJ, Laragh JH: Left ventricular mass as a predictor of development of hypertension. Am J Hypertens. 1991;4:603-7. [CrossRef]

11. Levy D, Savage DD, Garrison RJ, Anderson KM, Kannel WB, Castelli WP. Echocardiographic criteria for left ventricular hypertrophy: the Framingham Heart Study. Am J Cardiol. 1987;59:956-60. [CrossRef]

12. Ganau A, Devereux RB, Roman MJ, et al. Patterns of left ventricular hypertrophy and geometric remodeling in essential hypertension. J Am Coll Cardiol. 1992;19:1550-8. [CrossRef]

13. Foley RN, Parfrey PS, Sarnak MJ. Epidemiology of cardiovascular disease in chronic renal disease. J Am Soc Nephrol. 1998;9[Suppl]:16-23.

14. Myhre PL, Omland T, Sarvari SI, Ukkonen H, Rademakers F, Engvall JE et al. Cardiac Troponin T Concentrations, Reversible Myocardial Ischemia, and Indices of Left Ventricular Remodeling in Patients with Suspected Stable Angina Pectoris: a DOPPLER-CIP Substudy. Clin Chem. 2018 Sep;64(9):1370-9. [CrossRef]

15. Cheriex EC, Leunissen KML, Janssen JHA, Mooy JMV, Van Hooff JP. Echocardiography of the inferior vena cava is a simple and reliable tool for estimation of dry weight in hemodialysis patients. Nephrol Dial Transplant. 1989;4:563-8.

16. Wang TJ, Levy D, Benjamin EJ, Vasan RS: The epidemiology of "asymptomatic" left ventricular systolic dysfunction: implications for screening. Ann Intern Med. 2003;138:907-16. [CrossRef] 
17. Koc M, Toprak A, Tezcan H, Bihorac A, Akoglu E, Ozener IC. Uncontrolled hypertension due to volume overload contributes to higher left ventricular mass index in CAPD patients. Nephrol Dial Transplant. 2002;17:1661-6. [CrossRef]

18. Foley RN, Parfrey PS, Harnett JD, Kent GM, Murray DC, Barre $\mathrm{PE}$ : The prognostic importance of left ventricular geometry in uremic cardiomyopathy. J Am Soc Nephrol. 1995;5:202431.

19. Nişancı Y, Sezer M, Umman B, Yılmaz E, Umman S,Ozsaruhan O. Relationship between pressure-derived collateral blood flow and diabetes mellitus in patients with stable angina pectoris: a study based on coronary pressure measurement. J Invasive Cardiol. 2002;14:118-22.

20. Fava S, Azzopardi J, Agius-Muscat H. Outcome of unstable angina in patients with diabetes mellitus. Diabet Med. 1997;14:209-13. [CrossRef]

21. Harnett JD, Foley RN, Kent GM, Barre PE, Murray D, Parfrey PS: Congestive heart failure in dialysis patients: prevalence, incidence, prognosis and risk factors. Kidney Int. 1995;47:88490. [CrossRef] 